Extended Abstract

\title{
Theoretical Foundations of Pastoral Care in Christian Tradition
}

\author{
Zuhâl Ağllkaya-Şahin ${ }^{1}$ \\ İzmir Kâtip Çelebi University
}

\begin{abstract}
The growing academic and institutional interest in pastoral care and counseling raises attention day by day. However there is no institutionally established concept and practice of pastoral care in Turkey's prevalent Islamic tradition. Therefore there is a lack of theoretical foundation for this service that wants to be developed and established in Turkey. In fact pastoral care services are quite well developed in Christian tradition. Especially in Germany pastoral care and counseling has a deep-rooted history and professional practice. Thus in this paper in order to give an insight into theoretical foundations of German pastoral care and counseling the concept is illustrated in terms of definition, characteristics, subjects, objects, aims, tasks and theology.
\end{abstract}

\section{Keywords}

Pastoral care $\bullet$ Pastoral counseling $\bullet$ Christianity $\bullet$ Germany

\footnotetext{
1 Correspondence to: Zuhâl Ağılkaya-Șahin, Department of Psychology of Religion, Faculty of Divinity, Izmir Kâtip Çelebi University, İzmir 35620 Turkey. Email: zuhal.agilkaya.sahin@ikc.edu.tr

Citation: Ağılkaya-Şahin, Z. (2016). Theoretical foundations of pastoral care in Christian tradition. Spiritual Psychology and Counseling, 1, 68-77. http://dx.doi.org/10.12738/spc.2016.1.0002
} 
Pastoral care as defined and institutionalized in Christian tradition does not exist within Turkish-Islamic context. What pastoral care here refers to is actually called by a different name in this paper and in Turkish. As explained in the text, the term pastoral stems from Christian tradition and has no equivalent counterpart within Turkish language or tradition. In order to make a correct translation, therefore, the expression of spiritual care (manevi bakim) is much more appropriate when talking about pastoral care in Turkey. Spiritual care and counseling is an expression that is widely accepted in both Turkish academia and institutions. The growing institutional and academic interest in spiritual care requires a theoretical foundation upon which a concept of solid spiritual care can be built. Therefore, an insight into Christian theory and tradition should be helpful.

With this intention I have examined pastoral care in Germany because pastoral care is performed institutionally and quite professionally in this country. The German word for pastoral care is Seelsorge, which literally means soul care. Seelsorge expresses the same notion as the terms pastoral care and counseling in Anglo-Saxon language use. The Latin word pastoral is also very well-established in the German language; it is used to address Church services in general and pastoral care and counseling in particular. The terms Seelsorge and pastoral are mostly used interchangeably. As defined in this paper, Seelsorge actually points to a conversation in a religious or churchly context which aims for the salvation of the individual. With the growing influence of human sciences, especially psychology and psychotherapy, pastoral care has lost its religious character and evolved into a kind of counseling where the psychological well-being of the counselee is in the foreground. This change in the pastoral paradigm started in Christian culture with the impact of the pastoral care movement that left from the USA and reached the European continent, first in the Netherlands then spreading out to Germany around 1970. This paradigm shift from kerygmatic pastoral care to therapeutic pastoral care was reinforced by the emergence of pastoral psychology. Pastoral psychology, as defined by Stollberg (1993, p. 169), is "psychology in the service of the pastoral (Seelsorge)." Pastoral psychology aims to help individuals with their religious and non-religious problems through a religious framework of interdisciplinary work, namely theology and human/social sciences. Hence pastoral psychology interprets religious and church services from a psychological point of view. The qualities of soul care and pastoral counseling have been discussed in detail in the related literature (Becker, 1985; Bonhoeffer, 1990, p. 9; Faber \& Schoot, 1974, p. 151; Gerkin, 1991; Grözinger, 1986; Gruehn, 1926, as cited in Wintzer, 1988; Hertzsch, 1967, p. 41; Hiltner, 1950, p. 7, 1952, p. 23; Johnson, 1953, pp. 26, 33; Keilbach, 1969, p. 257; Naurath, 2000; Nidetzky, 1990; Oursin \& Schuster, 2008; Piper, 1985; Pohl-Patalong, 1996; Rössler, 1962; W. Schmid, 1998, p. 248; G. Schmid, 1998; Weiler, 1980; Ziemer, 2011b).

After the introduction of the basic terms, this paper proceeds with headings such as The Concept of Pastoral Care. The German concept of Seelsorge, as mentioned above, is comprised of the verb sorgen, which has two basic meanings: to care for 
(in the sense of caring for someone, to be concerned with and help someone) and to worry about someone or to fear for someone (in the sense of feeling fear, or being restless and troubled over someone).

The evolution of the concept of pastoral care in Western tradition shows traces from Greek philosophy, the Bible, and Roman traditions. Caring for souls first emerged in Socrates' Apology, where he appealed to the young to care for their souls instead of favoring property or their reputations. Such definitions of pastoral care (Seelsorge) do not exist in either the Old or New Testaments. Nevertheless, the phenomenon is well present within these sacred texts (Klaus, 1968; Steiger, 2000; Ziemer, 2011a; Klessmann, 2010, pp. 55-56).

The Early Church adopted the metaphor of shepherding, which is implicit in the term pastoral, and regarded its services to the community as pastoral work. During the Middle Age, the Latin term cura animarum (soul care; Riedel-Pfaefflin, 2002) occurred and became a technical term in Church law. Cura animarum is the broadest meaning of pastoral care and comprises all acts that lead to the salvation of the soul which are performed in the name of God (Algermissen, 1937). This general aspect of pastoral care was called cura animarum generalis. In addition to this general service, clergy also cared for their community members individually. This kind of pastoral care and counseling was narrower in meaning and named cura animarum specialis. This special pastoral care and counseling has accompanied individuals on their personal journeys of faith in times of crisis, conflict, and critical transition. This notion of pastoral care is based on talents and attributes emphasized in the Bible, such as consolation, resolution, counseling, and healing. This kind of therapeutic pastoral care (Stollberg, 1969) can be defined as "help throughout life in the context of the church" (Neidhardt as cited in Zerfass, 1988, p. 1118).

Over the course of time, the Catholic Church's understanding of cura animarum generalis remained valid so that pastoral care and counseling comprised all the duties of the clergy. On the other hand the Protestant Church adopted the narrower sense of pastoral care and counseling, cura animarum specialis, and focused on direct personal intervention as an individual service to a human's soul.

The German translation of cura animarum as Seelsorge occurred at the end of the Middle Ages with the start of the Reformation (Steiger, 2000). It was assumed (Stollberg, 1996) that the word Seelsorge was first used in Brant's Narrenschrift (1494). However, one should note that the terms Seelsorge and Seelsorger (the person) are not legally protected yet the right for pastoral care and counseling are constitutional rights.

With the rise of pastoral psychology at the beginning of the $20^{\text {th }}$ century, pastoral care and counseling gained an interdisciplinary character in its interactions with human, 
social, and counseling sciences. The pastoral care movement that started in the USA with its concept of a special training (clinical pastoral training) and different approaches to methodology has contributed to the independent development of pastoral care.

The next section, Definition and Characteristics of Pastoral Care, refers to German literature, which has often mentioned that defining pastoral care was not easy (Geest, 1981; Klessmann, 2010; Wulf, 1970; Thurneysen, 1988). This difficulty also exists within American literature (see Greenwald et al., 2004). Today, the widely accepted definition in Germany is that of Rössler (1986, p. 210): "Pastoral care is help for life safety." According to many authors (Geest, 1981, pp. 223-225; Klessmann, 2010; Wiedemann, 2011, p. 233) pastoral care has characteristics like religious communication and private conversation; it takes social and political circumstances into consideration, includes religious rituals, accompanies people in times of crises, addresses everyday themes and problems, values occasional services, and collaborates with diaconal services.

Pastoral care is widely accepted as an encounter and relationship in which both the context of Church and religious content are clear. The pastoral counselor, who is generally a clergy member, represents the Church. The religious dimension is the ultimate concern in the relationship. Thus pastoral care and counseling is marked with establishing a relationship to God and with prayer. These two things are typical religious rituals in pastoral care that reinforce religious experience, which is another trait of this service. The relationship that is established in each encounter is with the counselee and their self, other people, and God. This can also be found in the New Testament as a command (Matthew 22:37-39). The greatest commandment is to love God, and the relationships that arise from this commandment (Leviticus 19:18) are the starting point of pastoral care and counseling for many authors. However people also tend to establish relationships beyond the emotion of love. These relationships can be destructive and harmful to life. Therefore pastoral care and counseling is seen as help for life; it releases people from false relationships and help them to reorder their relations.

Furthermore, the pastoral relationship takes place as an absolutely discrete conversation; it is limited in time with a focus on solving a problem by concentrating on the whole individual (emotions, behavior, nonverbal reactions, etc.) and addressing conscious and unconscious processes. It strengthens personal potentials and skills. Surely, no one can be forced to take part in a relationship like this. Thus pastoral care and counseling is an offer that people can accept or reject freely (Asmussen, 1934; Clinebell, 1971; Hauschildt, 2000; Klessmann, 2010; Scharfenberg, 1972; Sticht, 2001; Thurneysen, 1988; Wiedemann, 2011; Ziemer, 2000).

The prevalent theories on pastoral care in Germany are described next in this paper. Scientific pastoral care theories emerged in the modern era. Among these, two have 
been noted as the most influential ones to mark Germany's pastoral care practices of today: theological-kerygmatic pastoral care and psychological-therapeutic pastoral care. Theological pastoral care theories have a religious characteristic and aim; they are mostly labeled as conservative notions. Representatives of this theory have defined pastoral care as "help in improving people's religious and ethical development" (Klessmann, 2010, p. 58). In contrast, the therapeutic (counseling), accompanying, accepting, and client-centered psychological approaches predict a therapeutically competent form of counseling based on the Christian faith and on accompanying people in times of crises (Klessmann, 2010, p. 76). Thus, this understanding of pastoral care has been described as "psychotherapy in the context of the Church" by Stollberg (1972, p. 33).

Therapeutic pastoral counseling is an outcome of the pastoral care movement that started in the 1940s in the USA and reached Europe between 1960 and 1970. With this movement, which had been a reaction to the kerygmatic paradigm, the concept, subject, aim, and education of pastoral care and counseling changed. Henceforth, pastoral care was concerned with the whole individual and the entirety of her/his body and soul, with her/his needs and potentials. To be able to perceive the individual in this way, pastoral counselors need to be trained and to acquire specific methods. In this sense, the pastoral care movement can also be seen as a training or education movement that has transferred the notion of a charismatic pastoral counselor to a professional and competent one (Denkers, personal communication, 15 September, 2011; Klessmann, 2010, pp. 76, 82; personal communication 28 April 2011; Matthes, 2000, p. 390; Stollberg, 1978, p. 72; Winkler, 2000, p. 51).

The following heading is about The Subject and Object of Pastoral Care. Stollberg (D. Stollberg, personal communication, 28 April, 2011) stated that because "they believe in a God who performs pastoral care, all Christians give pastoral care to each other." These words reflect in one sentence the object and subject of pastoral care and counseling. Over the course of time, the characteristics of the subjects (from sinner to soul to counselee) or the objects (from God to Jesus to the Church to all Christians) have changed somewhat, but Stollberg's description has remained valid. Be it the human soul or the community, ultimately it is the human who needs and practices pastoral care. The only difference is how the human is seen throughout different eras and paradigms. For instance while theological concepts focus on the sinner as one who is in need of guidance for salvation and purification (Hauschildt, 2000; Happle, 2008; Tacke, 1975; Thurneysen, 1988, p. 26; Winkler, 1983), psychological approaches address the person in crisis as one who needs empathy, acceptance, and a companion in her/his pain (Clinebell, 1971, pp. 14-17). Concepts that do not assess humans within the deficit model, such as the therapeutic and theological approaches, see pastoral care as an interaction that helps one move on to create and realize something. Thus, "Pastoral care provides mutual help, enforcement, and possibilities" 
(Kehlbreier, 2013, p. 16). These different understandings are the subject of the section Aims and Tasks of Pastoral Care. The aims and tasks of pastoral care and counseling also vary according to time and approach. As kerygmatic approaches view the task of pastoral care and counseling as spreading the word of God, they thus aim for the human to approach and establish a relationship with God (Tacke, 1975; Winkler, 1983; Hauschildt, 2000); psychological approaches see their task in accompanying and standing by people in times of pain and suffering.

When examining the literature, one can see that the aims of pastoral care and counseling have been categorized according to theological and general aims. Theological aims strive for a better religious life, which ideally means achieving religious and ethical sense (Achelis, 1906; Happle, 2008). Next to these religious aims, pastoral care and counseling also has some general aims. Pastoral care and counseling occurs through conversations that encourage people. This can be seen as a process of reconstructing the self. The individual is shown how to view one's self externally by freeing the self from the things that have captured it (sin, pain, disease, etc.). As a result, the person learns to respect, control, and renew oneself (Zerfass, 1985, p. 53). This is what Baumgartner and Müller (1990) described as serving the human to become human. In today's words, this service can be expressed as a dialogue that helps the individual realize oneself. The self is set free to discover one's dignity and importance; the limited and threatened human being has been cured and completed. All of these aims can be reached by using Carl Roger's client-centered approach that requires unconditional positive regard.

According to Clinebell (1971, pp. 16-17), the task and aim of pastoral care and counseling is to help people cope with their problems, realize personal possibilities, and remove the obstacles that hinder them from establishing satisfying relations. When people are deprived of authentic love, they experience psychological symptoms and interpersonal conflicts. Clinebell (1971, p. 15) described this authentic love as loving and being loved. The lack of this emotion and the following pain eventually lead people to either a counselor or a pastor. As Clinebell (1971, pp. 14-17) stated, pastoral care and counseling is effective as long as it helps to improve communication skills. Thus pastoral care and counseling can help people to cope with carrying the burden and responsibility of problems, to develop personal possibilities, to establish constructive relations, and to make their relationship with God more meaningful.

In the last part, I have attempted an outline of the Theology of Pastoral Care by demonstrating how it was embedded in Christian scripture. As mentioned earlier, God is the first pastoral counselor, and the New Testament recommends pastoral care in many verses. God performs pastoral care by means of His worldly representatives: first being Jesus Christ, then his apostles, the Church, clerics, and finally, all Christian believers (Bukowski, 1994, p. 17; Kehlbreier, 2013; Steiger, 2000; Tacke, 1975). 
The Lord described in the Old and New Testaments is God, who is present with and near to humans (John 1:18; Colossians 1:15) and who cares for them and is concerned with them. God, who is the healer (Exodus 15:26), the merciful protector, and helper (Hebrews 4:15; Isaiah 41:10), cares for the survival of the soul (Peter 5:7) (Bukowski, 1994, p. 17; Kehlbreier, 2013; Steiger, 2000; Tacke, 1975). Jesus initially passed the task of pastoral care to his apostles and then to all believers (John 21:15, Ephesians 4:11; 1 Peter 5:2-4). Thus, the pastoral counselor follows Jesus in helping, accepting, visiting (Luke 15:2, 19:10; John 4:7-10, 8:1-9), and approaching people as a whole (Mark 2:1-12). According to the Bible, pastoral care and counseling is a reflection of the greatest pastor, Jesus, whose acts strengthened, healed, consoled, and taught; Jesus suffered together and felt with his people. The Lord is also trustful, which is also expected from a pastoral counselor: People should be able to trust, lean on, and commit themselves to their pastoral counselor.

Love is a profound source for pastoral care and counseling. In Christian belief, God is recognized as love. By virtue of this love, God approaches people, cares for them, opens Himself to them, and consoles them in difficult times (Ziemer, 2000, p. 111). God fulfilled these acts with Jesus, through whom communication between Him and His believers was realized (Romans 8:15). This kind of communication is another example of the practices of pastoral care and counseling. The pastoral counselor approaches counselees through communication that is marked with love and empathy.

Certainly such a relationship with God cannot be forced or imposed on the counselee. This kind of communication and relationship may exist between God and the pastoral counselor, but this does not mean that the counselee can be forced to be part of this relationship. However, in the pastoral relation that is established between the pastoral counselor and the counselee, the counselee can join, establish, or find this relationship again. In this sense, pastoral care can be argued to have the function of reestablishing lost relations or contact with God (see Thuneysen, 1988; Ziemer, 2000).

Even though the term pastoral care and counseling cannot be found in the scripture, today's elements of pastoral care are understood to include consolation (2 Corinthians 13:11, 1:5-7; 1 Thessalonians 4:18; Romans 12:8, 5:14), exhortation (1 Thessalonians 2:11, 5:11; 1 Timothy 4:13; Titus 2:15), closeness and care (Philippians 4:3; 1 Corinthians 12:25; 2 Corinthians 11:28), servitude toward each other (1 Peter 4:10), encouragement and hope (1 Thessalonians 5:14; 2 Thessalonians 2:16), and counseling (Colossians 3:16), as expressed in the New Testament (Kehlbreier, 2013; Steiger, 2000; Ziemer, 2000, p. 115). Further verses like 1 Corinthians 12:25-26 reflect the Early Church's notions of pastoral care and counseling (cura animarum). Verses such as Luke 10:9, 5:17; Matthew 4:23; Mark 1:34 are references for today’s 
pastoral care in hospitals and for the sick. Other biblical sources for pastoral care and counseling that have been mentioned in literature and by many pastoral caregivers are Matthew 25:35-36, 25:40; Romans 12:15, and more.

The Bible also shows traces of typical elements from the therapeutic aspect of pastoral care and counseling. These elements and their corresponding verses are: empathy, "He is able to deal gently with those who are ignorant and go astray since he himself is subject to weakness" (Hebrews 5:2); acceptance, "Accept one another, then, just as Christ accepted you, in order to bring praise to God" (Romans 15:7); hope, "But in your hearts revere Christ as Lord. Always be prepared to give an answer to everyone who asks you to give the reason for the hope that you have. But do this with gentleness and respect" (1 Peter 3:15).

In the Conclusion, the German understanding of pastoral care and counseling is argued to be able to differ according to the theological or psychological paradigms from which it had arose, according to the era and theory it belongs. Due to this fact, it would not make sense to directly transfer these Christian religious services into the context of Turkish Muslims. However Turkey can benefit from German professional theory and practice when adopting spiritual care and counseling services into its own religious and spiritual traditions.

\section{Kaynakça/References}

Achelis, E. C. (1906). Seelsorge. Realencyklopaedi für protestantische Theologie und Kirche, $18,132-145$.

Algermissen, K. (1937). Seelsorge. Lexikon für Theologie und Kirche, 9, 416-422.

Asmussen, H. (1934). Die Seelsorge: Ein praktisches Handbuch über Seelsorge und Seelenführung. München, Germany: C. Kaiser.

Baumgartner, K., \& Müller, W. (1990). Beraten und Begleiten. Handbuch für das Seelsorgerliche Gespraech. Freiburg, Germany: Herder.

Becker, H. (1985). Einleitung in Michel Foucaults "Hermeneutik des Subjekts." In M. Foucault, \& H. Becker (Eds.), Freiheit und Selbstsorge (pp. 29-31). Frankfurt, Germany: Materialis Verlag.

Bonhoeffer, T. (1990). Zur Enstehung des Begriffes Seelsorge. Archiv für Begriffsgeschichte, $33,7-21$.

Bukowski, P. (1994). Die Bibel ins Gespraech bringen. Neukirchen-Vluyn, Germany: Neukirchener.

Clinebell, H. J. (1971). Modelle beratender Seelsorge. München, Germany: Kaiser.

Deutscher Evangelischer Kirchenausschuss. (1960). Die Bekenntnisschriften der evangelischlutherischen Kirche (1930). Göttingen, Germany: Evang. Verl-Anst.

Faber, H., \& Schoot, E. V. (1974). Praktikum des Seelsorgerlichen Gespraechs. Göttingen, Germany: Vandenhoeck \& Ruprecht.

Geest, H. V. D. (1981). Unter vier Augen. Zürich: Theologischer Verlag. 
Gerkin, C. V. (1991). On the art of caring. Journal of Psychology and Christianity, 45, 399-408.

Greenwald, C. A., Greer, J. M., Gillespie, C. K., \& Greer, T. V. (2004). A Study on the identity of pastoral counselors. American Journal of Pastoral Counselors, 7(4), 51-69.

Grözinger, A. (1986). Seelsorge als Rekonstruktion von Lebensgeschichte. Wege zum Menschen, 38, 178-188.

Happle, M. (2008). Biblische Seelsorge-Worum geht es? Evangelium für Alle-Nachrichten, $1(1), 7-10$.

Hauschildt, E. (2000). Seelsorge, Seelsorgelehre. Theologische Realenzyklopaedie, 31, 31-74.

Hauschildt, E. (2003). Mein Auftrag, meine Fachkompetenz, meine Rolle-Seelsorgerliche Identität zwischen Eigenem und Erwartetem. Ekir-Evangelische Kirche im Rheinland. Retrieved from http://www.ekir.de/krankenhausSeelsorge/Downloads/Vortrag_Hauschildt.pdf

Hertztsch, E. (1967). Aerztliche und pastorale Psychotherapie. Forschung und Fortschritte, $41,40-44$.

Hiltner, S. (1950). The meaning of pastoral psychology. Pastoral Psychology, 1(4), 7-8.

Hiltner, S. (1952). Pastoral psychology and pastoral counseling. Pastoral Psychology, 3(8), $21-28$.

Johnson, P. E. (1953). Psychology of pastoral care. New York, NY: Abingdon.

Kehlbreier, D. (2013). Seelsorgeverbatim - Besuch bei einem aelteren Gemeindeglied. Dietmar Kehlbreier. Retrieved from http://www.dietmar - kehlbreier.de/cms/_data/Seelsorge.pdf

Keilbach, W. (1969). Religionspsychologie. Sacramentum Mundi. Theologisches Lexikon für die Praxis, 254-272, Freiburg: Herder.

Klaus, B. (1968). Seelsorgerliche Begegnung mit dem modernen Menschen im Blick auf die "Neue Moral." Theologia Practica, 3(3), 242-261.

Klessmann, M. (2010). Seelsorge. Neukirchen-Vluyn, Germany: Neukirchener.

Luther, H. (1986). AlltagsSeelsorge und Seelsorge: Zur Kritik am Defizit Modell des Helfens. Wege zum Menschen, 38, 2-17.

Luther, M. (1928). Martin Luthers Werke: Kritische Gesamtausgabe (Vol. 21). Weimar, Germany: H. Böhlhaus Nachfolger.

Matthes, J. (2000). Fremde Heimat Kirche. Gütersloh, Germany: Gütersloher Verl. - Haus.

Müller, J. (1998). Pastoral. In Lexikon für Theologie und Kirche (Vol. 7, p. 1434). Freiburg: Herder.

Naurath, E. (2000). Seelsorge als Leibsorge. Stuttgart, Germany: Kohlhammer.

Nidetzky, W. (1990). Allgemeine Ziele der Seelsorgerlichen Beratung und Begleitung. In K. Baumgartner \& W. Müller (Eds.), Beraten und Begleiten - Handbuch für das Seelsorgerliche Gespraech (pp. 51-60). Freiburg, Germany: Herder.

Oursin, C., \& Schuster, R. (2008). Ehrenamtlich in der Seelsorge. Klinikum Nürnberg. Retrieved from http://www.klinikum.nuernberg.de/klinikum/kliniken/dienste/Seelsorge/ fachinformationen/oekum/Ehrenamt1.html

Piper, H.-C. (1985). Der Hausbesuch des Pfarrers: Hilfen für die Praxis. Göttingen, Germany: Vandenhoeck \& Ruprecht.

Pohl-Patalong, U. (1996). Seelsorge zwischen Individuum und Gesellschaft. Element zu einer Neukonzeption der Seelsorgetheorie. Stuttgart, Germany: Kohlhammer.

Riedel-Pfaefflin, U. (2002). Seelsorge. Wörterbuch der Feministischen Theologie (pp. 497498). Gütersloh: Gütersloher Verl-Haus.

Rössler, D. (1962). Der “ganze” Mensch. Göttingen, Germany: Vandenhoeck \& Ruprecht. 
Rössler, D. (1986). Grundriss der Praktischen Theologie. Berlin, New York: Walter de Gruyter. Scharfenberg, J. (1972). Seelsorge als Gespraech. Göttingen, Germany: Vandenhoeck \& Ruprecht.

Scharfenberg, J. (1985). Einführung in die Pastoralpsychologie. Göttingen, Germany: Vandenhoeck \& Ruprecht.

Schmid, G. (1998). Pastoralpsychologie. Lexikon für Theologie und Kirche (7th ed., pp. 14411443). Freiburg, Germany: Herder.

Schmid, W. (1998). Philosophie der Lebenskunst. Frankfurt, Germany: Suhrkamp.

Seidmann, P. (1979). Religiöse und philosophische Wurzeln der Psychologie. In H. H. Balmer \& G. Condrau (Eds.), Psychologie des 20. Jahrhunderts (Vol. 15, pp. 353-365). Zürich, Germany: Kindler.

Steiger, J. A. (2000). Seelsorge - Kirchengeschichtlich. Theologische Realenzyklopaedie, 31, 7-31.

Sticht, F. (2001). Was ist Seelsorge. Zeitschrift für Lebensfragen (Vol 7, 8). Retrieved from http://www.efg-hohenstaufenstr.de/downloads/texte/Seelsorge-was-ist-das.pdf

Stollberg, D. (1969). Therapeutische Seelsorge. München, Germany: Kaiser.

Stollberg, D. (1972). Mein Auftrag deine Freiheit: Thesen zur Seelsorge. München, Germany: Claudius.

Stollberg, D. (1978). Wahrnehmen und Annehmen: Seelsorge in Theorie und Praxis. Gütersloh, Germany: Mohn.

Stollberg, D. (1993). Was ist Pastoralpsychologie 1992? Wege zum Menschen, 45, 168-172.

Stollberg, D. (1996). Seelsorge. Evangelisches Kirchenlexikon, 4, 173-188.

Stone, H. (2002). Revising the revised model: Howard Clinebell and his influence. American Journal of Pastoral Counseling, 6(1), 63-70.

Tacke, H. (1975). Glaubenshilfe als Lebenshilfe: Probleme und Chancen heutiger Seelsorge. Neukirchen-Vluyn, Germany: Neukirchener Verlag.

Thurneysen, E. (1988). Die Lehre von der Seelsorge. Zürich: Theol. Verl.

Weiler, R. (1980). Seelsorge. Katholisches Soziallexikon (pp. 2503-2507). Innsbruck: Tyrolia.

Wiedemann, W. (2011). Keine Angst vor der Seelsorge. Göttingen, Germany: Vandenhoeck \& Ruprecht.

Winkler, K. (1983). Seelsorge. Taschenlexikon Religion und Theologie, 5, $28-33$.

Winkler, K. (2000). Seelsorge. Berlin, New York: Vandenhoeck \& Ruprecht.

Wintzer, F. (1988). Seelsorge: Texte zum gewandelten Verstaendnis und zur Praxis der Seelsorge in der Neuzeit. München, Germany: Kaiser.

Wulf, H. (1970). Wege zur Seelsorge. Neukirchen, Germany: Vluyn.

Zerfass, R. (1985). Menschliche Seelsorge. Für eine Spiritualitaet von Priestern und Laein im Gemeindedienst. Freiburg, Germany: Herder.

Zerfass, R. (1988). Seelsorge - Begriffsvielfalt. In Praktisches Lexikon der Spiritualitaet (pp. 1117-1120). Freiburg: Herder.

Ziemer, J. (2000). Seelsorgelehre. Göttingen, Germany: Vandenhoeck \& Ruprecht.

Ziemer, J. (2011a). Pastoral care. Religion Past \& Present, 9, 583-585.

Ziemer, J. (2011b). Pastoral psychology. Religion Past \& Present, 9, 599-601. 